
\title{
$\begin{array}{ll}\text { Research Square } & \begin{array}{l}\text { Preprints are preliminary reports that have not undergone peer review. } \\ \text { They should not be considered conclusive, used to inform clinical practice, } \\ \text { or referenced by the media as validated information. }\end{array}\end{array}$
}

\section{Effect of growing season, Trichoderma and clinoptilolite applications on potentially toxic elements (PTEs) uptake by Cucumis melo L.}

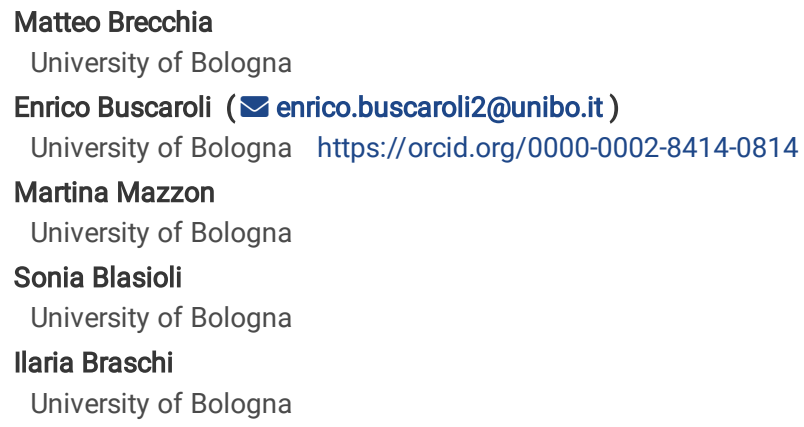

\section{Research Article}

Keywords: Heavy metals, Plant uptake, Food safety, Phytoremediation, Mycorrhization

Posted Date: December 1st, 2021

DOI: https://doi.org/10.21203/rs.3.rs-1086161/v1

License: @ (i) This work is licensed under a Creative Commons Attribution 4.0 International License. Read Full License 


\section{Abstract}

Aim:

The extent at which different agricultural strategies may affect the uptake of potentially toxic elements (PTEs) by cropped plants is not completely understood at a field scale. This study dealt with the effect of seasonality, Trichoderma inoculation alone or combined to different applications of commercial grade clinoptilolite (i.e., foliar action, fertigation, and pellet) on the PTEs content of early- and late-ripening cultivars Cucumis Melo L.

\section{Methods:}

Two similar field experiments were performed in spring and summer. For each cultivar/treatment combination, the input of PTEs (namely, $\mathrm{Cr}$, Cu, and Pb) to the soil-crop system through irrigation water, fertilizers, pesticides, and treatment products (i.e., Trichoderma and clinoptilolite products), as well as the PTE content of melon stem, leaves and fruit, were assessed through Inductively Coupled Plasma - Optic Emission Spectrometry.

\section{Results:}

Neither Trichoderma alone nor associated with clinoptilolite had visible effect on PTEs uptake by plants, while early season cultivation was strongly associated with lower uptake of $\mathrm{Cu}$ and $\mathrm{Pb}$. The high correlation of $\mathrm{Cu}$ and $\mathrm{Pb}$ content with $\mathrm{Ca}$ content in stem and leaves, used as a proxy for different transpiration rates under different growing seasons, indicated a possible uptake of these metals through Ca-nonselective cation channels as a drought stress defence. Lower $\mathrm{Cu}$ and $\mathrm{Pb}$ concentration were found in early-ripening melon fruit cultivated in spring.

\section{Conclusions:}

To the scope of $\mathrm{Cu}$ and $\mathrm{Pb}$ risk management, in case of significant contamination in Mediterranean calcareous soils, the use of early-ripening Cucumis melo L. cultivars in place of late-ripening ones is suggested.

\section{Introduction}

Beside the natural soil concentration of potentially toxic elements (PTEs), that originates from parent rock material, high PTEs concentration in cultivated soils are commonly due to anthropic industrial activities and to the agricultural use of amendments, fertilizers, and poorly treated water (He et al. 2005; Thornton 1981). High levels of $\mathrm{Cu}$ and $\mathrm{Zn}$ can accumulate in plants as they are actively assimilated as essential micronutrients (Clemens et al. 2002). Similarly, nonessential elements such as Pb, As, and Cd can be uptaken by the crops root system and be translocated into edible tissues (Lasat 2002; Sekara et al. 2005; Uchimiya et al. 2020).

Among the possible food safety risks, concentration of PTEs into crops below the allowed maximum limits, and thus not causing adverse health effects (Buscaroli et al. 2021), may represent a cause of food quality non-compliance to stricter market demands. This is the case of PTE such as copper. The use of Cu salts as copper sulphate, commonly referred to as a Bordeaux mixture, is permitted with some limitations on several crops (melon included) within both integrated pest management (European parliament, 2009) and organic crop production. Cu-based products have been massively used in the last century due to their fungicidal properties (Lamichhane et al., 2018), thus contributing to raise Cu pool in cultivated soils (La Torre et al. 2018). Moreover, agriculture intensification, reduction of crop diversification, and the increasingly adopted practice of ploughing of crop residues (green manure) favoured Cu accumulation in soils (Lamichhane et al. 2018).

From an environmental point of view, the reduction of the heavy metals content in polluted soils is generally achieved through phytoremediation techniques (Ali et al. 2013), soil washing, and soil dilution (Dermont et al. 2008; Buscaroli et al. 2019). Otherwise, agricultural strategies aimed at mitigating the risk of PTEs entering the food chain, prevent their uptake and translocation through soil conditioning or pH corrections to reduce metal ion mobility and availability (Uchimiya et al. 2020).

Alternative remedies have been investigated by academia or proposed by professional horticulture companies. It is the case of all-purpose natural zeolitebased products, such as clinoptilolite, whose use in agriculture was proposed in past years because of their high cation exchange capacity and content of nutrients (Ramesh et al. 2011; Nakhli et al. 2017). More controversial is their use as PTEs immobilizers, as studies on clinoptilolite ability to stabilize PTEs are few and limited to peculiar applications (Leggo and Ledésert 2001; Leggo et al. 2006; Oste et al. 2002).

Another proposed strategy, currently evaluated to prevent PTEs translocation to crops, is soil treatment based on Trichoderma genus fungi inoculation. Trichoderma is a competitor of pathogenic fungi and can establish a mutualistic symbiotic endophytic association (mycorrhizae) with certain crops (Berg 2009; Woo et al. 2006). Recent studies pointed out the capacity of symbiotic Trichoderma to reduce micronutrient plant assimilation (Téllez Vargas et al. 2017; de Santiago et al. 2011), especially $\mathrm{Cu}$. This mechanism is of unclear origin, but it has been hypothesized that a competition between Trichoderma and the inoculated crop for micronutrients is involved. If confirmed in multiple tests and fully understood, Trichoderma association with crops cultivated in Cu-rich substrates could be a valuable strategy to reduce excessive $\mathrm{Cu}$ accumulation.

Melon (Cucumis melo L.) is the third most largely cultivated horticultural crop in Italy (Italian Institute of Statistics [ISTAT] 2021). The consumption of melon fruit peaked 9.5 annual kg per capita in 2020 (Services Institute for Agri-food Market [ISMEA] 2020). Italy is also the second larger European producer of this 
crop (Food and Agriculture Organization of United Nations [FAO] 2021). Like other geni of Cucurbitaceae family, melon may mobilize, uptake and translocate organic and inorganic contaminants (Campbell et al. 2009; Mattina et al. 2004; Mattina et al. 2006).

The present study was aimed at evaluating different agricultural strategies under integrated pest management for elucidating PTEs (i.e., $\mathrm{Cu}$, $\mathrm{Cr}$, and $\mathrm{Pb}$ ) uptake and translocation to different melon cultivars. Specifically, the effect of different applications of commercial grade clinoptilolites, Trichoderma inoculation and seasonality on PTEs content of three different melon cultivars was evaluated. In parallel, a detailed mass balance of the PTEs entered the soil-crop system through irrigation water, fertilization and pest management was assessed. Results indicated that Trichoderma alone or combined to clinoptilolite treatments did not have any effect on PTEs uptake, while early season cultivation was strongly associated with lower $\mathrm{Cu}$ and Pb uptake.

\section{Materials And Methods Experimental field and bulk soil analysis}

The experimental field was in Viadana municipality, Italy $\left(44^{\circ} 58^{\prime} 21^{\prime \prime} \mathrm{N}, 10^{\circ} 35^{\prime} 11^{\prime \prime} \mathrm{E}\right)$ within the productive area of Agricola Don Camillo Srl (Figure 1$)$, one of the biggest producers of melon fruit in Italy. The plot used for the trials had an extension of 0.5 ha.

Before the beginning of the experimental trial, on June 1, 2020, a bulk soil sampling was performed. The soil was sampled according to non-systematic "W" pattern sampling. Four soil carrots of $30 \mathrm{~cm}$ of depth were collected at positions shown in Figure 1 . The soil sampling was established at the depth of the expected melon root development. Single soil carrots were homogenized, air-dried, manually grinded and sieved at $2 \mathrm{~mm}$. Sieved soil samples were analysed for pH (International Organization for Standardization [ISO] 2021), electrical conductivity (EC) (ISO 1994), total organic carbon (TOC) (ISO 1995a), total nitrogen (TN) (ISO 1995b), and total carbonates (ISO 1995c). Particle size distribution was determined by the pipette method (Gee and Bauder 1986) using sodium hexametaphosphate as a dispersant.

Pseudo-total metal content of soil samples was determined through microwave acid digestion (ISO 2012). Digested extracts were filtered through Whatman no. 42 filter paper and analysed by inductively coupled plasma optical emission spectroscopy (ISO 2008a), using an ICP-OES Spectro Arcos (Ametek,

Germany).

The fraction of potentially available-to-plant metal content was assessed by diethylentriaminopentaacetic acid (DTPA) extraction, adapting the method from Lindsay and Norwell (1969). The DTPA-extractable metal fraction is considered a useful proxy for the determination of element potential bioavailability for plants in alkaline soils (Lindsay and Norvell 1978). Briefly, soil samples were added to a DTPA solution $\left(1.97 \mathrm{~g} \mathrm{~L}^{-1} \mathrm{DTPA}_{1} 1.46 \mathrm{~g} \mathrm{~L}^{-1} \mathrm{CaCl}_{2} \cdot 2 \mathrm{H}_{2} \mathrm{O}, 14.92 \mathrm{~g} \mathrm{~L}^{-1}\right.$ triethanolamine) with 1:2 w:v ratio, at pH 7.3, shaken for $2 \mathrm{~h}$, filtered through Whatman no. 42 paper, and analysed by ICP-OES.

All the analyses were performed in triplicate.

\section{Field trials}

Three cultivars of Cucumis melo L. were selected for experimental cultivation: Django, an early-ripening cultivar, along with Costantino and 504, both lateripening cultivars. All cultivars were provided by HM.Clause.

In 2020, two field trials with a duration of 84 days each were performed with the three varieties during spring (Time 1: planted on April 2 and harvested on June 25) and summer (Time 2: planted on June 1 and harvested on August 24). The planting layout provided for rows get in line on growth beds of $20 \mathrm{~cm}$ high from ground level. The distance between rows was $2 \mathrm{~m}$ and, along the row, the distance between plants was $1 \mathrm{~m}$. The cultivars were planted according to the scheme indicated in Figure 1. The three cultivars were subjected to fertilization and protection according to integrated pest management protocol that are reported as a supporting information in Table SI1.

At both growing periods (Time 1 and 2) and on all the three crop varieties, different treatments were evaluated: (i) mycorrhization alone or combined to application of clinoptilolite (ii) for foliar action, (iii) in fertigation, and (iv) pellet.

The acronyms of the different treatments are reported as follows:

- C: control not treated.

- M: mycorrhization with Trichoderma.

- MFA: mycorrhization with Trichoderma and application of clinoptilolite for foliar action.

- MFT: mycorrhization with Trichoderma and application of clinoptilolite in fertigation.

- MP: mycorrhization with Trichoderma and application of clinoptilolite pellet.

The products used, the dosage and the application conditions for mycorrhization and clinoptilolite treatments are reported as a supporting information in Table SI1.

A weather station ECO 4M (DigitEco Srl., Italy) was installed at $20 \mathrm{~m}$ hight from ground level in close proximity to the experimental plot (44 ${ }^{\circ} 58^{\prime} 17^{\prime \prime} \mathrm{N}$, $\left.10^{\circ} 35^{\prime} \mathrm{O} 3^{\prime \prime} \mathrm{E}\right)$ for meteorological data collection. The average daily temperature, rainfall, and relative humidity of the period corresponding to the two experimental trials are reported as a supporting information in Figure SI1. The average daily temperature showed a trend with tendency to increase from $13^{\circ} \mathrm{C}$ at the first day of the experimentation (April 2) to $22.5^{\circ} \mathrm{C}$ at the last one (August 20). During the first growing season, the total amount of rainfall was $126 \mathrm{~mm}$ 
spread over 31 days, whereas, during the second one, it was $197 \mathrm{~mm}$ spread over 26 days. The average relative humidity curve shows a variable trend with peaks of $90 \%$ corresponding to rainy days.

\section{Metal analysis of fertilizers, pesticides, and products used for treatments}

Pseudo-total metal content of the fertilizers, the pesticides and the mycorrhization product used in the trials were determined through wet acid attack on flame. Briefly, $5 \mathrm{~g}$ of each sample were placed in a $250 \mathrm{~mL}$ wide neck flask. In general, $21 \mathrm{~mL}$ of hydrochloric acid ( $37 \% \mathrm{HCl}$ for trace analysis, by Honeywell, Fluka) and $7 \mathrm{~mL}$ of nitric acid $\left(65 \% \mathrm{HNO}_{3}\right.$ for trace analysis, by Honeywell, Fluka) were added to the sample, and the mixture was heated on Bunsen flame and brought to boiling. Only for organic fertilizers (namely, Lieta Veg, Agriges and Examine $L \AA, K \& A$ ), digestion was completed adding, during boiling, a further volume of $65 \%$ nitric acid and few $\mathrm{mL}$ of $30 \%$ hydrogen peroxide (for electronic use, Honeywell, Fluka) until complete dissolution of the solid matrix. Pseudototal metal content of the clinoptilolite-based products were determined though microwave acid digestion adding to $0.250 \mathrm{~g}$ of each sample, $6 \mathrm{~mL}$ of $\mathrm{HCl}$ (37\%), $2 \mathrm{~mL}$ of $\mathrm{HNO}_{3}(65 \%), 2 \mathrm{~mL}$ of $\mathrm{HF}$ (40\% for trace analysis, by Honeywell, Fluka) and $0,5 \mathrm{~mL}$ of $\mathrm{H}_{2} \mathrm{O}_{2}(30 \%)$.

The digestates obtained were filtered through Whatman no. 42 filter paper, diluted to $20 \mathrm{ml}$ with milliQ® water and analysed by ICP-OES.

The metal fraction potentially available-to-plants of fertilizers, pesticides and products used for treatments was assessed on DTPA extracts as already described for soil at Section 2.2.

All the analyses were performed in triplicate.

\section{Irrigation protocol and water analysis}

The irrigation was performed with water from a freshwater canal that is adjacent to the experimental field (see Figure 1) through a drop-by-drop system equipped with a unit control that allowed to measure the water daily distributed to the experimental field rows. The volume of irrigation water used separately for crops during the first and second growing periods was 192 and $218 \mathrm{~m}^{3}$, respectively.

The irrigation water was monthly collected and characterized. On April 15, May 15, June 15, July 15, and August 15, 2020, a sample (10 L) of water was collected from the suction pipe connected to the freshwater canal. Water samples were filtered by Whatman $0.45 \mu \mathrm{m}$ pore size nylon membrane filter to separate suspended solids from the liquid phase (ISO 1997). Both liquid and soil fractions were analysed.

Filtered water was characterized for $\mathrm{pH}$ (ISO 2008b), EC (ISO 1985), and total metals content. Total metal content analysis was carried out by adding $0.15 \mathrm{~mL}$ of nitric acid $\left(\mathrm{HNO}_{3}-1 \% \mathrm{~V} / \mathrm{v}\right)$ to $15 \mathrm{~mL}$ of each filtered water sample and analysed by ICP-OES.

Suspended solids were air-dried, grinded and analysed as well for pseudo-total metals content through microwave acid digestion (ISO 2012). Digested samples were filtered through Whatman no. 42 filter paper and analysed by ICP-OES (ISO 2008a).

\section{All the analyses were performed in triplicate.}

\section{Sample plants preparation and metal content analysis}

At the end of each trial period, when most melon fruits were considered ripe for the market (i.e., July 25 and August 24, 2020, for Time 1 and 2, respectively), the epigeal portion of one single plant per variety per treatment per growing period (for a total of 30 plants) was collected at the positions shown in Figure 1. The plants collected had a variation of the epigeal biomass within $\pm 10 \%$. Non-ripe fruit was discarded. Each plant was then divided into three subsamples: stem, leaves and fruit. Plant parts were first thoroughly washed with tap water and then rinsed with deionized water. The parts were then dried into a ventilated oven at $60^{\circ} \mathrm{C}$ for $72 \mathrm{~h}$, and finally ground with a food blender. The variation of the dry mass of all parts for each plant was $<10 \%$. Water content of fruit samples was determined as a ponderal loss.

For each plant part (stem, leaves, and fruit), trace element analysis was performed. The metals content of the plant parts was determined through microwave acid digestion using $3: 1 \mathrm{v} / \mathrm{v}$ ratio of $65 \%$ nitric acid and $30 \%$ hydrogen peroxide. After digestion, the solutions were filtered and analysed by ICP-OES. The analyses were performed in triplicate.

\section{Statistical analysis}

Statistical analysis of the data on metals content in the epigeal plants biomass (stem, leaves, and fruit) was conducted using R environment (R Core Team 2020). The effects of variety, treatment and time were assessed using a split-split plot ANOVA ( $p$-value $<0.05)$, followed by an LSD post hoc test ( $p$-value $<$ 0.05) with Bonferroni adjustment. The differences of metal content in the different epigeal fractions of plants (stem, leaves, fruit) for the two time of transplanting considered, were tested with a two-way ANOVA ( $p$-value $<0.05$ ) followed by an LSD post hoc test ( $p$-value $<0.05)$ with Bonferroni adjustment. The correlation matrix of the metal concentration in plant parts was computed using Pearson's correlation coefficient.

\section{Results}

\section{Characterization of soil, irrigation water, fertilizers, pesticides, and treatment products}

The characteristics of the experimental soil plot, irrigation water, and all products used for crop production are reported as a supporting information in Table SI2, SI3, and SI4, respectively. 
The soil was silty clay loam, according to USDA classification system, with an average alkaline $\mathrm{pH}\left(\mathrm{pH}_{\mathrm{H} 20}: 8.8 ; \mathrm{pH}_{\mathrm{CaCl}}: 8.0\right)$ that was in line with its total carbonate content (7.8\%) (Table SI2). The soil had low salinity $\left(E C=0.15 \mathrm{ds} \mathrm{m}^{-1}\right)$ and a well-endowment of TOC and TN $(1.43$ and $0.23 \%$, respectively), according to quality criteria defined for surrounding soils (ARPAV 2007).

Among PTEs, the average total content of $\mathrm{Cr}\left(205.0 \pm 2.9 \mathrm{mg} \mathrm{kg}^{-1}\right)$ was found to largely exceed the legal threshold of $150 \mathrm{mg} \mathrm{kg}^{-1}\left(\mathrm{D} . \mathrm{Lgs}^{\mathrm{N}} \mathrm{N}^{\circ} 4601 / 03 / 2019\right)$ (Table SI2). Moreover, the total content of Cu at sampling positions $1\left(114.1 \pm 1.4 \mathrm{mg} \mathrm{kg}^{-1}\right)$ and $3\left(99.2 \pm 3.9 \mathrm{mg} \mathrm{kg}^{-1}\right)$ slightly exceeded the threshold of 100 $\mathrm{mg} \mathrm{kg}^{-1}$. The average total content of Pb was safely far from the legal threshold. Nevertheless, the PTE was reported in the Table because of its peculiar accumulation profile in melon crop as it is discussed farther on. The potential bioavailability-to-plant content, expressed as a percentage of the total content, was in the order: $\mathrm{Cu}>\mathrm{Pb}>\mathrm{Cr}(11.1,7.5$, and $0.01 \%$ of the corresponding average total content, respectively, Table SI2).

As far as the characterization of irrigation water samples that were monthly collected from April to August 2020 was concerned (Table SI3), the samples were similar for $\mathrm{pH}\left(8.0\right.$ - 8.4) and EC (from 0.258 to $0.271 \mathrm{dS} \mathrm{m}^{-1}$ ), except for that collected on April 15 ( $\mathrm{pH}=9.5$; EC $=0.479 \mathrm{dS} \mathrm{m}^{-1}$ ). In the Table, the metal total amount of irrigation water is given as a sum of the amount contained in the filtered water and in the suspended solids contained within. Cr and $\mathrm{Pb}$ were found only in the suspended solids of the water samples with concentrations $\leq 0.049$ and $\leq 0.016 \mathrm{mg} \mathrm{L}^{-1}$, respectively. Cu was found in both filtered water and suspended solids with total content $\leq 0.027 \mathrm{mg} \mathrm{L}^{-1}$ as a sum of the two components. In general, all the water parameters were compliant to international water quality standards for irrigation water (Pescod 1992).

The total content and the bioavailable fraction of PTEs of all the products used for crop production (namely, fertilizers, pesticides, clinoptilolite and mycorrhizal products) is reported, as a supporting information, in Table S14. Among the products, Poltiglia Disperss contained the highest amount of Cu (19099 $\left.\mathrm{mg} \mathrm{kg}^{-1}\right), 38.66 \%$ of which was assessed potentially bioavailable-to-plant (DTPA extractable). Appreciable levels of Pb were found in the mycorrhizal product Tusal (47.62 mg kg$\left.{ }^{-1}\right)$ and in the three clinoptilolite-based products $\left(20.65-38.62 \mathrm{mg} \mathrm{kg}^{-1}\right)$ with measurable bioavailable fractions in the formulates for fertigation and foliar action only (16.7 and $13.0 \%$ of the total, respectively). Low levels of $\mathrm{Cr}$ were found in pesticides $\left(\leq 9.33 \mathrm{mg} \mathrm{kg}{ }^{-1}\right)$ and in clinoptilolite samples ( $\leq 13.76 \mathrm{mg} \mathrm{kg}^{-1}$ ) with bioavailable percentages low and highly variable among the products.

\section{PTEs input through irrigation water and products for crop production}

The metal input of irrigation water to each crop-soil system corresponding to a given treatment was assessed by multiplying the total metal content of the water sample collected at day 15 of a given month by the volume of irrigation water distributed during the month to the corresponding field plot. The irrigation volume monthly distributed to each treatment for each growing period is given as a supporting information in Table SI5.

Table 1 reports the contribution of each agronomical activity (i.e., irrigation, fertilization, application of pesticides and treatment products) to the input of Cr, $\mathrm{Cu}$, and $\mathrm{Pb}$ to the soil-crop system. Table 2 reports the total and potentially bioavailable-to-plant input of PTEs to the soil-crop system of different treatments. Here, the total $\mathrm{Cr}$ amounts received by different treatments was limited and in the range of $12.57-13.61 \mathrm{~g} \mathrm{ha}^{-1}$ at Time $1 \mathrm{and}^{\mathrm{a}} 17.88-18.91 \mathrm{~g}$ ha ${ }^{-1}$ at Time 2. As detailed in Table 1, the $\mathrm{Cr}$ main input at both growing periods was due to irrigation water $\left(12.14-17.58 \mathrm{~g} \mathrm{ha}{ }^{-1}\right)$ and, to a minor extent, to clinoptilolite pellet in MP treatment (1.03 $\mathrm{g} \mathrm{ha}^{-1}$ ). Nevertheless, as reported in Table 2, the bioavailable fraction that entered the soil-crop system was negligible in all treatments. Similar observations could be extended to the total input of $\mathrm{Pb}$ that was low and in the range of $2.86-8.70 \mathrm{~g}$ ha ${ }^{-1}$ at Time 1 and of $5.18-$

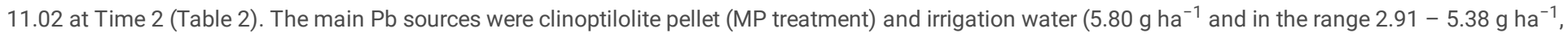
respectively) (Table 1) with no effect on the bioavailable portion (Table 2). On the contrary, for all treatments, the total input of Cu was high ( $\geq 810.1 \mathrm{~g}$ ha ${ }^{-1}$ ) and mainly due to Poltiglia Disperss (802.2 $\mathrm{g} \mathrm{ha}^{-1}$, Table S1) with a consistent bioavailable fraction (38.7\%, Table SI4). 
Table 1

PTES, Ca, and Si input $\left(\mathrm{g} \mathrm{ha}^{-1}\right)$ of irrigation water, fertilizers, pesticides, and trial products to the soil/crop system. Error expressed

\begin{tabular}{|c|c|c|c|c|c|}
\hline Element & $\mathrm{Cr}$ & $\mathrm{Cu}$ & $\mathrm{Pb}$ & $\mathrm{Ca}$ & Si \\
\hline \multicolumn{6}{|l|}{ Time 1} \\
\hline Irrigation Water & $12.14 \pm 3.552$ & $6.964 \pm 3.648$ & $2.908 \pm 1.228$ & $16018 \pm 2298$ & $247.4 \pm 112.4$ \\
\hline Fertilizers & $0.226 \pm 0.022$ & $0.300 \pm 0.036$ & $0.040 \pm 0.004$ & $708.4 \pm 30.62$ & $3.044 \pm 0.056$ \\
\hline Pesticides & $0.466 \pm 0.022$ & $802.4 \pm 0.844$ & $0.180 \pm 0.044$ & $3164 \pm 39.04$ & $704.0 \pm 60.46$ \\
\hline of which Poltiglia Disperss & $0.392 \pm 0.010$ & $802.2 \pm 0.810$ & $0.180 \pm 0.046$ & $3138 \pm 39.60$ & $59.80 \pm 27.72$ \\
\hline \multicolumn{6}{|l|}{ Treatments } \\
\hline Clinogold Clinoptilolite (pellet) & $1.030 \pm 0.040$ & $0.580 \pm 0.180$ & $5.800 \pm 0.240$ & $298.5 \pm 10.20$ & $4733 \pm 123.8$ \\
\hline Clinogold Clinoptilolite (fertigation) & $0.100 \pm 0.040$ & $0.080 \pm 0.010$ & $0.210 \pm 0.020$ & $18.77 \pm 0.080$ & $309.6 \pm 9.650$ \\
\hline Rock Powder Clinoptilolite (foliar action) & $0.100 \pm 0.010$ & $0.070 \pm 0.010$ & $0.220 \pm 0.010$ & $12.77 \pm 1.260$ & $219.5 \pm 5.330$ \\
\hline Tusal (fertigation) & $0.005 \pm 0.001$ & $0.008 \pm 0.001$ & $0.045 \pm 0.001$ & $0.803 \pm 0.003$ & $1.003 \pm 0.063$ \\
\hline \multicolumn{6}{|l|}{ Time 2} \\
\hline Irrigation Water & $17.58 \pm 1.206$ & $11.63 \pm 0.382$ & $5.380 \pm 0.956$ & $22234 \pm 414.0$ & $340.0 \pm 15.19$ \\
\hline Fertilizers & $0.266 \pm 0.030$ & $0.550 \pm 0.088$ & $0.052 \pm 0.003$ & $886.8 \pm 38.80$ & $2.676 \pm 0.010$ \\
\hline Pesticides & $0.466 \pm 0.022$ & $802.4 \pm 0.844$ & $0.180 \pm 0.044$ & $3164 \pm 39.04$ & $704.0 \pm 60.46$ \\
\hline of which Poltiglia Disperss & $0.392 \pm 0.010$ & $802.2 \pm 0.810$ & $0.180 \pm 0.046$ & $3138 \pm 39.60$ & $59.80 \pm 27.72$ \\
\hline \multicolumn{6}{|l|}{ Treatments } \\
\hline Clinogold Clinoptilolite (pellet) & $1.030 \pm 0.040$ & $0.580 \pm 0.180$ & $5.800 \pm 0.240$ & $298.5 \pm 10.20$ & $4733 \pm 123.8$ \\
\hline Clinogold Clinoptilolite (fertigation) & $0.100 \pm 0.040$ & $0.080 \pm 0.010$ & $0.210 \pm 0.020$ & $18.77 \pm 0.080$ & $309.6 \pm 9.650$ \\
\hline Rock Powder Clinoptilolite (foliar action) & $0.100 \pm 0.010$ & $0.070 \pm 0.010$ & $0.220 \pm 0.010$ & $12.77 \pm 1.260$ & $219.5 \pm 5.330$ \\
\hline Tusal (fertigation) & $0.005 \pm 0.001$ & $0.008 \pm 0.001$ & $0.045 \pm 0.001$ & $0.803 \pm 0.003$ & $1.003 \pm 0.063$ \\
\hline
\end{tabular}

Considering the overall PTEs input to the soil-plant system due to irrigation and agricultural practices, Cu input resulted homogeneously distributed among treatments because of the same main input (copper salts). On the other hand, $\mathrm{Cr}$ and $\mathrm{Pb}$ input varied among treatments within the same growing periods and increased from the first to the second growing period mainly because of the different volume and composition of irrigation water.

\section{Effect of variety, treatments, and seasonality on PTEs uptake by crop}

Figure 2 shows $\mathrm{Cr}$, $\mathrm{Cu}$ and $\mathrm{Pb}$ content in the aboveground plant biomass, for each treatment, in both growing periods. The Ca content in plants was reported, as a proxy for verifying a differential transpiration rate (Marschner 2011; McLaughlin and Wimmer 1999; White and Broadley 2003) under different growing seasons. The Si content was reported as well, due to the claim reported by some clinoptilolite-based products, foliar action especially, to be able to create a silica-film coating to protect the leaves by external pathogens, (De Smedt et al. 2015).

In Figure 2, the $\mathrm{Cr}$ levels in plants did not show statistically different concentrations either among treatments or between growing periods. As far as $\mathrm{Cu}$, $\mathrm{Pb}$, and Ca were concerned, no differences among treatments were observed for plants within the same growing period, whereas statistically significant differences resulted between Time 1 and Time 2. The $\mathrm{Cu}, \mathrm{Pb}$ and $\mathrm{Ca}$ uptake resulted, on average, about three $\left(69.25-187.0 \mathrm{mg} \mathrm{kg}^{-1}\right)$, four $\left(0.214-0.885 \mathrm{mg} \mathrm{kg}{ }^{-1}\right)$ and seven (2384 - $\left.18254 \mathrm{mg} \mathrm{kg}^{-1}\right)$, respectively, times higher at Time 2 with respect to Time 1 (Figure 2).

In Figure 3 marginal means of the metal uptake of each cultivar (namely, 504, Costantino, and Django) in the two growing periods were reported. The three cultivars did not uptake statistically different amounts of $\mathrm{Cr}$ and $\mathrm{Si}$, neither within the same growing period nor between the two growing periods. Moreover, the $\mathrm{Cu}, \mathrm{Pb}$, and $\mathrm{Ca}$ uptake of the cultivars was not statistically different within the same growing period.

The trend in metals uptake by melon plants shown in Figures 2 and 3 highlighted the lack of significant variability among both treatments and melon cultivars.

Figure 4 shows the marginal means of metal content in the stem, leaves, and fruit of plants grown at Time 1 and Time 2 . Statistically significant differences in $\mathrm{Cr}, \mathrm{Cu}$, and $\mathrm{Pb}$ accumulation among the plant parts were observed. The higher plant uptake of $\mathrm{Pb}$ and $\mathrm{Cu}$ at Time 2 with respect to Time 1 seems to mostly affect leaves and stem $(\mathrm{Pb})$ or leaves only $(\mathrm{Cu})$. The fruit resulted to be the least accumulating plant part for $\mathrm{Cu}$ and $\mathrm{Pb}$. In fruit, $\mathrm{Cu}$ content did not seem to be affected by seasonality of growing period, while $\mathrm{Pb}$ content seems to be partially affected (Figure 4). On a dry weight basis, the increase of Cu average concentration in fruit at Time 2 with respect to Time 1 resulted moderate (15.83 and $13.68 \mathrm{mg} \mathrm{kg}^{-1} \mathrm{dw}$, respectively) whereas the increase of Pb, on average, was more consistent ( 0.224 and $0.064 \mathrm{mg} \mathrm{kg}^{-1} \mathrm{dw}$, respectively). 
As strong differences in $\mathrm{Cu}, \mathrm{Pb}$, and $\mathrm{Ca}$ concentration were observed from Time 1 and Time 2 in plant parts, the Pearson correlation $(r)$ matrix for the metals in the plant parts was calculated (Table 3). As a result, positive correlations were observed both between $\mathrm{Ca}$ and $\mathrm{Cu}$ or $\mathrm{Pb}$ in leaves ( $r=0.84$ and 0.76 , respectively) and stem ( $r=0.89$ and 0.74 , respectively), thus supporting the figure that absorption and translocation of $\mathrm{Pb}$ and $\mathrm{Cu}$ are correlated with $\mathrm{Ca}$ uptake.

Table 3

Pearson's correlation coefficients matrix of $\mathrm{Cu}, \mathrm{Pb}$ and $\mathrm{Ca}$ content of fruit, leaves, and stem.

\begin{tabular}{|c|c|c|c|c|c|c|c|c|c|c|c|c|}
\hline & $\begin{array}{l}\text { Cu in } \\
\text { fruit }\end{array}$ & $\begin{array}{l}\text { Cu in } \\
\text { leaves }\end{array}$ & $\begin{array}{l}\text { Cu in } \\
\text { stem }\end{array}$ & $\begin{array}{l}\text { Cr in } \\
\text { fruit }\end{array}$ & $\begin{array}{l}\text { Cr in } \\
\text { leaves }\end{array}$ & $\begin{array}{l}\mathrm{Cr} \text { in } \\
\text { stem }\end{array}$ & $\begin{array}{l}\mathrm{Pb} \text { in } \\
\text { fruit }\end{array}$ & $\begin{array}{l}\mathrm{Pb} \text { in } \\
\text { leaves }\end{array}$ & $\begin{array}{l}\mathrm{Pb} \text { in } \\
\text { stem }\end{array}$ & $\begin{array}{l}\text { Ca in } \\
\text { fruit }\end{array}$ & $\begin{array}{l}\text { Ca in } \\
\text { leaves }\end{array}$ & $\begin{array}{l}\text { Ca in } \\
\text { stem }\end{array}$ \\
\hline $\begin{array}{l}\text { Cu in } \\
\text { fruit }\end{array}$ & 1 & & & & & & & & & & & \\
\hline $\begin{array}{l}\text { Cu in } \\
\text { leaves }\end{array}$ & $0.46^{*}$ & 1 & & & & & & & & & & \\
\hline $\begin{array}{l}\text { Cu in } \\
\text { stem }\end{array}$ & $0.38^{*}$ & $0.84^{\star \star}$ & 1 & & & & & & & & & \\
\hline $\mathrm{Cr}$ in fruit & 0.07 & -0.31 & -0.35 & 1 & & & & & & & & \\
\hline $\begin{array}{l}\text { Cr in } \\
\text { leaves }\end{array}$ & 0.3 & -0.03 & -0.07 & -0.09 & 1 & & & & & & & \\
\hline $\begin{array}{l}\text { Cr in } \\
\text { stem }\end{array}$ & -0.04 & $-0.59 * \star$ & $-0.53^{\star \star}$ & 0.63 ** & 0.29 & 1 & & & & & & \\
\hline $\begin{array}{l}\mathrm{Pb} \text { in } \\
\text { fruit }\end{array}$ & 0.25 & $0.43^{*}$ & $0.42^{\star}$ & 0 & 0.32 & 0.03 & 1 & & & & & \\
\hline $\begin{array}{l}\mathrm{Pb} \text { in } \\
\text { leaves }\end{array}$ & 0.34 & $0.47^{\star \star}$ & $0.47^{\star \star}$ & -0.3 & $0.59 * *$ & -0.23 & 0.26 & 1 & & & & \\
\hline $\begin{array}{l}\mathrm{Pb} \text { in } \\
\text { stem }\end{array}$ & $0.5^{\star \star}$ & $0.53^{\star \star}$ & $0.58^{\star \star}$ & -0.28 & $0.45^{\star}$ & -0.24 & 0.25 & $0.63^{* *}$ & 1 & & & \\
\hline $\begin{array}{l}\text { Ca in } \\
\text { fruit }\end{array}$ & $0.46^{*}$ & $0.84 \star \star$ & $0.76^{\star \star}$ & $-0.44^{*}$ & 0.13 & $-0.59 * \star$ & 0.28 & 0.72 ** & $0.7^{\star *}$ & 1 & & \\
\hline $\begin{array}{l}\text { Ca in } \\
\text { leaves }\end{array}$ & $0.45^{\star}$ & 0.84 ** & $0.78^{\star \star}$ & $-0.46^{*}$ & 0.21 & $-0.55^{\star \star}$ & 0.34 & $0.76^{* *}$ & $0.75^{\star \star}$ & $0.97 * *$ & 1 & \\
\hline $\begin{array}{l}\text { Ca in } \\
\text { stem }\end{array}$ & $0.4^{*}$ & $0.83^{\star \star}$ & $0.89 * \star$ & $-0.43^{*}$ & 0.14 & $-0.52^{\star *}$ & $0.44^{*}$ & $0.7^{\star \star}$ & $0.74^{\star *}$ & $0.92^{\star *}$ & $0.95^{\star \star}$ & 1 \\
\hline
\end{tabular}

As far as the quality of melon fruit was concerned, the effect of variety and growing seasonality on $\mathrm{Cu}$ and $\mathrm{Pb}$ content of fruit was reconsidered on a fresh weight basis. In Table 4, the marginal means of $\mathrm{Cu}$ and $\mathrm{Pb}$ concentration in the fresh fruit are reported. Cu concentration in fresh fruit ranged from $1.88 \mathrm{mg}$ $\mathrm{kg}^{-1}$ in Django variety to $2.22 \mathrm{mg} \mathrm{kg}^{-1}$ in Costantino variety. Despite a slight tendency, no significant effect of variety on Cu concentration was assessed. With respect to $\mathrm{Pb}$, its concentration in fresh fruit spaced from a value of $0.01 \mathrm{mg} \mathrm{kg}^{-1}$ in Costantino to $0.027 \mathrm{mg} \mathrm{kg}^{-1}$ in Django. Again, no significant effect of the variety, as well as of variety:time interaction, was found under the two-way ANOVA. The only significant factor was the growing period. Cu and Pb concentration in fresh fruit cultivated at Time 2 increased by $25 \%(p<0.001)$ and $312 \%(p=0.044)$, respectively, respect to Time 1 . 
Table 4

\begin{tabular}{|c|c|c|}
\hline \multicolumn{3}{|c|}{$\begin{array}{l}\text { Marginal means of } \mathrm{Cu} \text { and } \mathrm{Pb} \\
\text { content in the fresh fruit (mg kg } \\
\text { fresh weight). Different lower case } \\
\text { letters indicate significant } \\
\text { differences ( } \mathrm{p} \text {-value }<0.05 \text { ) as } \\
\text { determined by the Fisher's LSD } \\
\text { test. }\end{array}$} \\
\hline & $\mathrm{Cu}$ & $\mathrm{Pb}$ \\
\hline \multicolumn{3}{|l|}{ Variety } \\
\hline Costantino & 2.22 & 0.010 \\
\hline Django & 1.88 & 0.027 \\
\hline 504 & 1.91 & 0.025 \\
\hline$p$-value & 0.044 & 0.462 \\
\hline \multicolumn{3}{|l|}{ Time } \\
\hline Time 1 & $1.77^{\mathrm{b}}$ & $0.008^{b}$ \\
\hline Time 2 & $2.23^{a}$ & $0.033^{a}$ \\
\hline$p$-value & $<0.001$ & 0.044 \\
\hline \multicolumn{3}{|c|}{ Variety*Time } \\
\hline p-value & 0.738 & 0.959 \\
\hline
\end{tabular}

In all cases, fruit was safely edible for the EU market according to the current maximum concentration of $\mathrm{Pb}$ and $\mathrm{Cu}$ permitted in melon fruit of 0.1 and 5 mg $\mathrm{kg}^{-1}$ fresh weight, respectively (European Commission, 2006; European Commission, 2008).

\section{Discussion}

\section{PTEs pool in soil}

Concerning the total amount of PTEs in soil (Table SI2), it is generally accepted that the compliance with the legal threshold for PTEs in soils is not mandatory in case their background values are higher than the threshold. This was the case of $\mathrm{Cr}$ and $\mathrm{Cu}$, whose available background value in the neighbouring soils (151 mg kg${ }^{-1}<\mathrm{Cr}<225 \mathrm{mg} \mathrm{kg}^{-1} ; 61 \mathrm{mg} \mathrm{kg}^{-1}<\mathrm{Cu}<120 \mathrm{mg} \mathrm{kg}^{-1}$ ), made available by the Regional Agency for Environmental Protection (ARPAE) report "The heavy metal background maps of the Emilia-Romagna plain" (2020), was respected.

When potentially available-to-plants PTE fraction was considered, Cu and Pb showed a considerably higher availability with respect to Cr (Table SI2). Notably, in alkaline soils the bioavailability of $\mathrm{Cu}$ and $\mathrm{Pb}$ is mainly due to their forms as carbonates or complexed by the negatively charged moieties of soil organic matter (Alloway 2012; Shahid et al. 2012). In these forms, PTEs are suitable to be complexed by plant-derived carboxylates and then to be absorbed by roots. On the contrary, the unavailability of $\mathrm{Cr}$ for plants is mainly due to its ability to form stable and insoluble species in soils already at natural pH values (Alloway 2012; Shahid et al. 2017).

\section{PTEs input due to irrigation}

The physical and chemical characteristics of the monthly sampled irrigation water was rather homogeneous, with the sole exception of the sample collected on April 15 (Table SI3). The sample showed the highest $\mathrm{pH}$ value and EC with respect to the others. Such a high pH could be reasonably explained to larger input to the water canal of ammonia coming from surrounding cropped fields owing to the use of animal-based fertilizers/amendments locally produced by intensive animal farming, very extended in the area. The interruption of animal-based fertilizer distribution in later periods, and in general in summer, brought the $\mathrm{pH}$ to more neutral values in the water samples that were subsequently collected $(\mathrm{pH} \leq 8.4)$. Moreover, the high value of suspended solids in water lastly sampled (July 15 and August 15) could be reasonably explained by the drier conditions of the summer period. Despite the bigger amount (+56\%) of rainfall at Time 2 with respect to Time 1, in the last two months of Time 2, only a few rainy days and four heavy rainfalls occurred (Figure SI1). The drier summer conditions imposed an irrigation volume for the crop at Time 2 larger (+14\%) than that used at Time 1 (218 and $192 \mathrm{~m}^{3}$, respectively).

\section{Effect of seasonality on PTEs translocation to plant}

Likely, the Cr uptake by plants produced under different treatments and growing seasons (Figure 2) was flattened by its unavailability either in soil (Table SI2) and in its input to the soil-crop system through irrigation water and products for crop production (Table 2). Similarly, Si content of plants did not statistically differ among treatments and between the growing periods, thus ruling out any detectable accumulation in plant trials treated with clinoptilolite-based products (namely, pellet, fertigation product, and foliar action product in MP, MFT, and MFA treatments, respectively).

With respect to $\mathrm{Ca}, \mathrm{Cu}$ and $\mathrm{Pb}$, their considerably higher average uptake assessed during Time 2 with respect to Time 1 was not supported by a proportional increase of their total and potentially bioavailable input to the soil-crop system through irrigation water and products for crop production at Time 2 (Table 2 ). 
More likely, the higher uptake was due to a higher nutrient flux through the soil-root-shoot system following the climate variation between the two growing

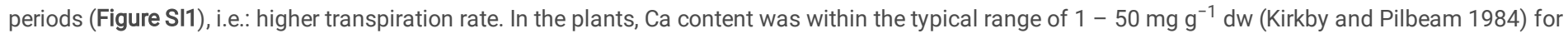
higher vascular plants.

Largely, $\mathrm{Ca}$ is absorbed by roots through passive diffusion following water influx (Kirkby and Pilbeam 1984). The diffusion is mediated by Ca-nonselective cation channels (Ca-NSCCs), specialised transmembrane pores permeable to different cations, that activate/deactivate upon ion flux or different stimuli (e.g., environmental stress) (Demidchik et al. 2002). These channels are involved in several defence processes against heat stresses (Naeem et al. 2020) and act as a heat sensor which causes hyperaccumulation of $\mathrm{Ca}$ and others compatible solutes, such as sugars, and increases photosynthetic activities. Moreover, Ca signal transduction has a role in leaf surface temperature regulation by regulating stomatal conductance (Demidchick and Maathuis 2007). In cytosol, Ca level plays an essential function as a second messenger in the signal conduction between environmental factor and plant responses in terms of growth and development as well (Marshner 2011). Several studies indicated Ca-NSCCSs as a possible pathway for heavy metals uptake (Clemens 2006; Wang et al. 2007; Pourrut et al. 2008; Robinson et al. 2009; Gallego et al. 2012; Demidchick et al. 2018; Sanz et al. 2019) owing to the significant permeability for both monoand divalent-cations (Demidchick and Maathuis 2007). Moreover, positive correlation between transpiration flux increase and Cu and $\mathrm{Zn}$ uptake are commonly found (Tani and Barrington 2005a; Tani and Barrington 2005b).

As defined by several studies on plant metal uptake and translocation mechanisms, vacuole of leaf cells represents the main storage site for both excess nutrition elements and PTEs (Pilon-Smith, 2005; Kramer, 2010; Sharma et al., 2016). In our plants, as expected, leaves resulted to be the most accumulating fraction for all the considered metals, except for silicon. The metals translocation from roots to the above-ground tissues plays an ecological role as a detoxification and a herbivores defence strategy (Boyds et al. 2007; Rascio and Navari-lzzo 2011; Martinoia et al. 2012; Sharma et al. 2016).

In view of these observations, it was reasonable to suppose that, in our study, the increase in $\mathrm{Cu}$ and $\mathrm{Pb}$ uptake during the second growing season could be depending mainly on the signal activation of Ca channels in response to the higher evapotranspiration rate typical of summer growing period and the higher $(+14 \%)$ irrigation volume during Time 2 respect to Time 1, thus resulting in a higher accumulation of $\mathrm{Ca}$, especially, but also Cu and $\mathrm{Pb}$ due to the higher ion flux and diffusion.

\section{Conclusions}

The field study was conducted on a calcareous agricultural soil whose $\mathrm{Cr}$ and $\mathrm{Cu}$ contents were lower than the background levels but higher than legal threshold limits: a typical figure of intensively cropped soils that have been regularly fertilized, amended with composts, and treated with copper salts.

Under integrated pest management, the Cr uptake by Cucumis Melo L. was not affected by seasonality, early-or late-ripening varieties, and Trichoderma mycorrhization alone or combined with pellet, foliar action, and fertigation clinoptilolite-based treatments, thus confirming its well-known low availability to plants.

On the contrary, the uptake of Cu was significantly limited by early cultivation period and, thus, by early ripening varieties. A similar figure was observed with $\mathrm{Pb}$, whose soil content was abundantly lower than the Italian threshold concentration in soils. This result is of certain interest in reducing the uptake of Cu and $\mathrm{Pb}$, whose presence in food is regulated within EU, in case melon crop is cultivated in soils with sensible levels of these PTEs. The observed strong correlation between $\mathrm{Ca}$ uptake, used as a proxy of transpiration rate, and $\mathrm{Cu}$ and $\mathrm{Pb}$ accumulation, that affected leaves mostly, indicated Ca-nonselective cation channels as a possible main entry for the PTEs in the epigeal biomass.

With respect to the market quality of fresh fruit, the lowest Cu concentration was found in the early-ripening Django cultivar. Tendentially, lower average Pb concentration were found in early cultivation season but no significant interaction between variety and growing period was found.

These results indicates that a possible strategy to mitigate $\mathrm{Cu}$ and $\mathrm{Pb}$ uptake by melon plants, as well as $\mathrm{Cu}$ and $\mathrm{Pb}$ concentration of fresh fruit, can be achieved anticipating the growing period of melons. Under field conditions, the cultivation of early-ripening cultivars had a significant impact in reducing the metal translocation and the Cu concentration in fruit.

To the scope of PTEs risk management, the results of the present study support the strategies aimed to use early-ripening cultivars in place of late-ripening ones in case a significant PTEs contamination is to be expected (i.e., soils with critical PTEs levels). Moreover, as most of Cu and Pb are accumulated in leave tissues, ploughing of crop residues should be limited as much as possible. More generally, manage Cu-based pesticides to avoid long-term accumulation in soil.

\section{Declarations}

\section{Acknowledgements}

Giampaolo Nitti (Department of Agricultural and Food Sciences and Technology - University of Bologna), Walter Benelli, llaria Orsi, Lorenzo Pezzali (Agricola Don Camillo), Sergio Guardigli, and Mauro Gallerani (HM.Clause Italia) are deeply thanked for their fundamental support to experimental design, field activities and fruitful discussion.

\section{Funding}

Research project supported by Agricola Don Camillo SrL and HM.Clause Italia.

\section{Competing Interests}


The authors have no relevant financial or non-financial interests to disclose.

\section{Author Contributions}

Ilaria Braschi and Sonia Blasioli contributed to the study conception and design. Material preparation, data collection and analysis were performed by Matteo Brecchia, Enrico Buscaroli, and Martina Mazzon. The first draft of the manuscript was written by Matteo Brecchia and all authors commented on previous versions of the manuscript. All authors read and approved the final manuscript.

\section{References}

1. Ali H, Khan E, Sajad MA (2013) Phytoremediation of heavy metals-Concepts and applications. Chemosphere 91(7):869-881. https://doi.org/10.1016/j.chemosphere.2013.01.075

2. Alloway BJ (ed) (2012) Heavy metals in soils: trace metals and metalloids in soils and their bioavailability (Vol. 22). Springer Science \& Business Media ISBN: 978-94-007-4470-7

3. ARPAE report (2020) "The heavy metal background maps of the Emilia-Romagna plain"

4. ARPAV (2007) L'interpretazione delle analisi del terreno ISBN: 88-7504-115-6

5. Berg G (2009) Plant-microbe interactions promoting plant growth and health: Perspectives for controlled use of microorganisms in agriculture. Appl Microbiol Biotechnol 84(1):11-18. https://doi.org/10.1007/s00253-009-2092-7

6. Boyd RS (2007) The defence hypothesis of elemental hyperaccumulation: Status, challenges and new directions. Plant Soil 293:153-176

7. Buscaroli E, Sciubba L, Falsone G et al (2019) Calcium chloride washing of calcareous sediment from a freshwater canal: effect on the removal of potentially toxic elements and water aggregate stability. J Soils Sediments 19:3098-3107. https://doi.org/10.1007/s11368-019-02298-3

8. Buscaroli E, Braschi I, Cirillo C et al (2021) Reviewing chemical and biological risks in urban agriculture: A comprehensive framework for a food safety assessment of city region food systems. Food Control 126:108085. https://doi.org/10.1016/j.foodcont.2021.108085

9. Campbell S, Arakaki AS, Li QX (2009) Phytoremediation of heptachlor and heptachlor epoxide in soil by cucurbitaceae. Int J Phytoremediation 11(1):2838. https://doi.org/10.1080/15226510802363410

10. Clemens S (2006) Toxic metal accumulation, responses to exposure and mechanisms of tolerance in plants. Biochimie 88(11):1707-1719. https://doi.org/10.1016/j.biochi.2006.07.003

11. Clemens S, Palmgren MG, Krämer U (2002) A long way ahead: understanding and engineering plant metal accumulation. Trends Plant Sci 7(7):309-315. https://doi.org/10.1016/S1360-1385(02)02295-1

12. de Santiago A, Quintero JM, Avilés M, Delgado A (2011) Effect of Trichoderma asperellum strain T34 on iron, copper, manganese, and zinc uptake by wheat grown on a calcareous medium. Plant Soil 342(1-2):97-104. https://doi.org/10.1007/s11104-010-0670-1

13. De Smedt C, Someus E, Spanoghe P (2015) Potential and actual uses of zeolites in crop protection. Pest Manag Sci 71(10):1355-1367. https://doi.org/10.1002/ps.3999

14. Demidchik V, Maathuis FJM (2007) Physiological roles of nonselective cation channels in plants: from salt stress to signalling and development. Tansley review. New Phytol 175:387-405. https://doi.org/10.1111/j.1469-8137.2007.02128.x

15. Demidchik V, Davenport RJ, Tester M (2002) Nonselective cation channels in plants. Annu Rev Plant Biol 53:67-107. https://doi.org/10.1146/annurev.arplant.53.091901.161540

16. Demidchik V, Shabala S, Isayenkov S, Cuin TA, Pottosin I (2018) Calcium transport across plant membranes: mechanisms and functions. New Phytol 220:49-69. https://doi.org/10.1111/nph.15266

17. Dermont G, Bergeron M, Mercier G, Richer-Laflèche M (2008) Soil washing for metal removal: A review of physical/chemical technologies and field applications. J Hazard Mat 152(1):1-31. https://doi.org/10.1016/j.jhazmat.2007.10.043

18. European Commission (2006) Regulation No 1881/2006 of 19 December 2006 setting maximum levels for certain contaminants in foodstuffs (Text with EEA relevance). http://data.europa.eu/eli/reg/2006/1881/2020-07-01

19. European Commission (2008) Regulation No 149/2008 of 29 January 2008 amending Regulation (EC) No 396/2005 of the European Parliament and of the Council by establishing Annexes II, III and IV setting maximum residue levels for products covered by Annex I thereto (Text with EEA relevance). http://data.europa.eu/eli/reg/2008/149/oj

20. European P (2009) Directive 2009/128/EC of the European Parliament and of the Council of 21 October 2009 establishing a framework for Community action to achieve the sustainable use of pesticides (Text with EEA relevance) https://eur-lex.europa.eu/legal-content/EN/ALL/?uri=celex\%3A32009L0128

21. FAO (2021) Elaboration from FAOSTAT public repository http://www.fao.org/faostat/en/\#home accessed on 7th of May, 2021

22. Gallego SM, Pena LB, Barcia RA, Azpilicueta CE, lannone MF, Rosales EP, Zawoznik MS, Groppa MD, Benavides MP (2012) Unravelling cadmium toxicity and tolerance in plants: Insight into regulatory mechanisms. Environ Exp Bot 83:33-46. https://doi.org/10.1016/j.envexpbot.2012.04.006

23. Gee GW, Bauder JW (1986) Particle-size Analysis. In Methods of Soil Analysis, A. Klute (Ed.). https://doi.org/10.2136/sssabookser5.1.2ed.c15

24. He ZL, Yang XE, Stoffella PJ (2005) Trace elements in agroecosystems and impacts on the environment. J Trace Elem Med Biol 19(2):125-140. https://doi.org/10.1016/j.jtemb.2005.02.010

25. International Organization for Standardization (1985) Standard 7888. Soil quality - Water quality - Determination of electrical conductivity

26. International Organization for Standardization (1994) Standard 11265. Soil quality - Determination of the specific electrical conductivity 
27. International Organization for Standardization (1995a) Standard 10694. Soil quality - Determination of organic and total carbon after dry combustion (elementary analysis)

28. International Organization for Standardization (1995b) Standard 11261. Soil quality - Determination of total nitrogen - Modified Kjeldahl method

29. International Organization for Standardization (1995c) Standard 10693. Soil quality - Determination of carbonate content - Volumetric method

30. International Organization for Standardization (1997) Standard 11923. Water quality - Determination of suspended solids by filtration through glass-fibre filters

31. International Organization for Standardization (2008a) Standard 22036. Soil quality - Determination of trace elements in extracts of soil by inductively coupled plasma - atomic emission spectrometry. ICP - AES

32. International Organization for Standardization (2008b) Standard 10523. Water quality - Determination of pH

33. International Organization for Standardization (2012) Standard 12914. Soil quality - Microwave-assisted extraction of the aqua regia soluble fraction for the determination of elements

34. International Organization for Standardization (2021) Standard 10390. Soil, treated biowaste and sludge - . Determination of pH

35. ISMEA (2020) III quarter report on agri-food markets (original document in Italian) http://www.ismeamercati.it/flex/cm/pages/ServeAttachment.php/L/IT/D/1\%252F3\%252Ff\%252FD.feecc9a424fec668632f/P/BLOB\%3AID\%3D11130/E/

36. ISTAT (2021) Elaboration from public data. http://dati.istat.it/ accessed on 7th of May, 2021

37. Kirkby EA, Pilbeam DJ (1984) Calcium as a plant nutrient. Plant Cell Environ 7:397-405. https://doi.org/10.1111/j.1365-3040.1984.tb01429.x

38. Krämer U (2010) Metal Hyperaccumulation in Plants. Annu Rev Plant Biol 61:517-534. https://doi.org/10.1146/annurev-arplant-042809-112156

39. La Torre A, lovino V, Caradonia F (2018) Copper in plant protection: current situation and prospects. Phytopathologia Mediterranea 57(2):201-236. doi: https://doi.org/10.14601/Phytopathol_Mediterr-23407

40. Lamichhane JR, Osdaghi E, Behlau F et al (2018) Thirteen decades of antimicrobial copper compounds applied in agriculture. A review. Agron Sustain Dev 38:28. https://doi.org/10.1007/s13593-018-0503-9

41. Lasat MM (2002) Phytoextraction of toxic metals: A review of biological mechanisms. J Environ Qual 31(1):109-120. doi: https://doi.org/10.2134/jeq2002.1090

42. Leggo PJ, Ledésert B (2001) Use of an organo-zeolitic fertilizer to sustain plant growth and stabilize metallurgical and mine-waste sites. Miner Mag 65(5):563-570

43. Leggo PJ, Ledésert B, Christie G (2006) The role of clinoptilolite in organo-zeolitic soil systems used for phytoremediation. Sci Total Environ 363:1-10

44. Lindsay WL, Norvell WA (1969) Development of a DTPA micronutrient soil test. Agron. Abstr. p. 84

45. Lindsay WL, Norvell WA (1978) Development of a DTPA soil test for Zn, Fe, Mn and Cu. Soil Sci Soc Am J 42:421-428

46. Marschner H (2011) Mineral Nutrition of Higher Plants. Second Edition. Academic Press

47. Martinoia E, Meyer S, De Angeli A, Nagy R (2012) Vacuolar transporters in their physiological context. Annual review of plant biology 63:183-213. https://doi.org/10.1146/annurev-arplant-042811-105608

48. Mattina MJI, lannucci-Berger W, Eitzer BD, White JC (2004) Rhizotron study of cucurbitaceae: Transport of soil-bound chlordane and heavy metal contaminants differs with genera. Environ Chem 1(2):86-89. https://doi.org/10.1071/EN04048

49. Mattina MJI, Isleyen M, Eitzer BD, lannucci-Berger W, White JC (2006) Uptake by Cucurbitaceae of Soil-Borne Contaminants Depends upon Plant Genotype and Pollutant Properties. Environ Sci Tech 40(6):1814-1821. https://doi.org/10.1021/es051572s

50. McLaughlin SB, Wimmer R (1999) Tansley Review No. 104 - Calcium physiology and terrestrial ecosystem processes. New Phytol 142:373-417. https://doi.org/10.1046/j.1469-8137.1999.00420.x

51. Naeem M, Traub JR, Loescher W (2020) Exogenous calcium mitigates heat stress effects in common bean: a coordinated impact of photoprotection of PSII, up-regulating antioxidants, and carbohydrate metabolism. Acta Physiol Plant 42(12):1-13. https://doi.org/10.1007/s11738-020-03171-4

52. Rascio N, Navari-Izzo F (2011) Heavy metal hyperaccumulating plants: How and why do they do it? And what makes them so interesting? Plant Sci 180(2):169-181. https://doi.org/10.1016/j.plantsci.2010.08.016

53. Oste LA, Lexmond TM, Van Riemsdijk WH (2002) Metal Immobilization in Soils using Synthetic Zeolites. J Environ Qual 31:813-821. https://doi.org/10.2134/jeq2002.8130

54. Pescod MB (1992) Wastewater treatment and use in agriculture. Food and agriculture organization of the United Nations. (FAO) ISBN 92-5-103135-5

55. Pilon-Smits E (2005) Phytoremediation. Annu Rev Plant Biol 56(1):15-39. https://doi.org/10.1146/annurev.arplant.56.032604.144214

56. Pourrut B, Perchet G, Silvestre J, Cecchi M, Guiresse M, Pinelli E (2008) Potential role of NADPH-oxidase in early steps of lead-induced oxidative burst in Vicia faba roots. Plant Physiol 165(6):571-579. https://doi.org/10.1016/j.jplph.2007.07.016

57. R Core Team (2020) R: A language and environment for statistical computing. R Foundation for Statistical Computing, Vienna, Austria. https://www.Rproject.org/

58. Robinson BH, Bañuelos G, Conesa HM, Evangelou MW, Schulin R (2009) The phyto-management of trace elements in soil. CRC Crit Rev Plant Sci 28(4):240-266. https://doi.org/10.1080/07352680903035424

59. Sanz A, Pike S, Khan MA, Carrió-Seguí À, Mendoza-Cózatl DG, Peñarrubia L, Gassmann W (2019) Copper uptake mechanism of Arabidopsis thaliana highaffinity COPT transporters. Protoplasma 256(1):161-170. https://doi.org/10.1007/s00709-018-1286-1

60. Sekara A, Poniedziałek M, Ciura J, Jedrszczyk E (2005) Cadmium and lead accumulation and distribution in the organs of nine crops: Implications for phytoremediation. Polish Journal of Environ Studies 14(4):509-516

Page $11 / 15$ 
61. Shahid E, Pinelli C, Dumat C (2012) Review of Pb availability and toxicity to plants in relation with metal speciation; role of synthetic and natural organic ligands. J Hazard Mat 219-220:1-12. https://doi.org/10.1016/j.jhazmat.2012.01.060

62. Shahid M, Shamshad S, Rafiq M, Khalid S, Bibi I, Niazi NK, Dumat C, Rashid MI (2017) Chromium speciation, bioavailability, uptake, toxicity and detoxification in soil-plant system: A review. Chemosphere 178:513-533. https://doi.org/10.1016/j.chemosphere.2017.03.074

63. Sharma SS, Dietz KJ, Mimura T (2016) Vacuolar compartmentalization as indispensable component of heavy metal detoxification in plants. Plant Cell Environ 39(5):1112-1126. https://doi.org/10.1111/pce.12706

64. Tani FH, Barrington S (2005a) Zinc and copper uptake by plants under two transpiration rates. Part I. Wheat (Triticum aestivum L.). Environ Poll 38(3):538-547. https://doi.org/10.1016/j.envpol.2004.06.005

65. Tani FH, Barrington S (2005b) Zinc and copper uptake by plants under two transpiration rates. Part II. Buckwheat (Fagopyrum esculentum L.). Environ Poll 138(3):548-558. https://doi.org/10.1016/j.envpol.2004.06.004

66. Téllez Vargas J, Rodríguez-Monroy M, López Meyer M, Montes-Belmont R, Sepúlveda-Jiménez G (2017) Trichoderma asperellum ameliorates phytotoxic effects of copper in onion (Allium cepa L.). Environ Exp Bot 136:85-93. https://doi.org/10.1016/j.envexpbot.2017.01.009

67. Thornton I (1981) Geochemical Aspects of the Distribution and Forms of Heavy Metals in Soils. In: Lepp NW (ed) Effect of Heavy Metal Pollution on Plants: Metals in the Environment. Springer Netherlands, Dordrecht, pp 1-33

68. Uchimiya M, Bannon D, Nakanishi H, McBride MB, Williams MA, Yoshihara T (2020) Chemical Speciation, Plant Uptake, and Toxicity of Heavy Metals in Agricultural Soils. JAFC 68(46):12856-12869. https://doi.org/10.1021/acs.jafc.0c00183

69. Wang H, Shan X, Wen B, Owens G, Fang J, Zhang S (2007) Effect of indole-3-acetic acid on lead accumulation in maize (Zea mays L.) seedlings and the relevant antioxidant response. Environ Exp Bot 61(3):246-253. https://doi.org/10.1016/j.envexpbot.2007.06.004

70. White PJ, Broadley MR (2003) Calcium in plants. Ann Botany 92(4):487-511. https://doi.org/10.1093/aob/mcg164

71. Woo SL, Scala F, Ruocco M, Lorito M (2006) The molecular biology of the interactions between Trichoderma spp., phytopathogenic fungi, and plants. Phytopathology 96(2):181-185. https://doi.org/10.1094/PHYTO-96-0181

\section{Tables}

Due to technical limitations, Table 2 is only available as a download in the Supplemental Files section.

\section{Figures}

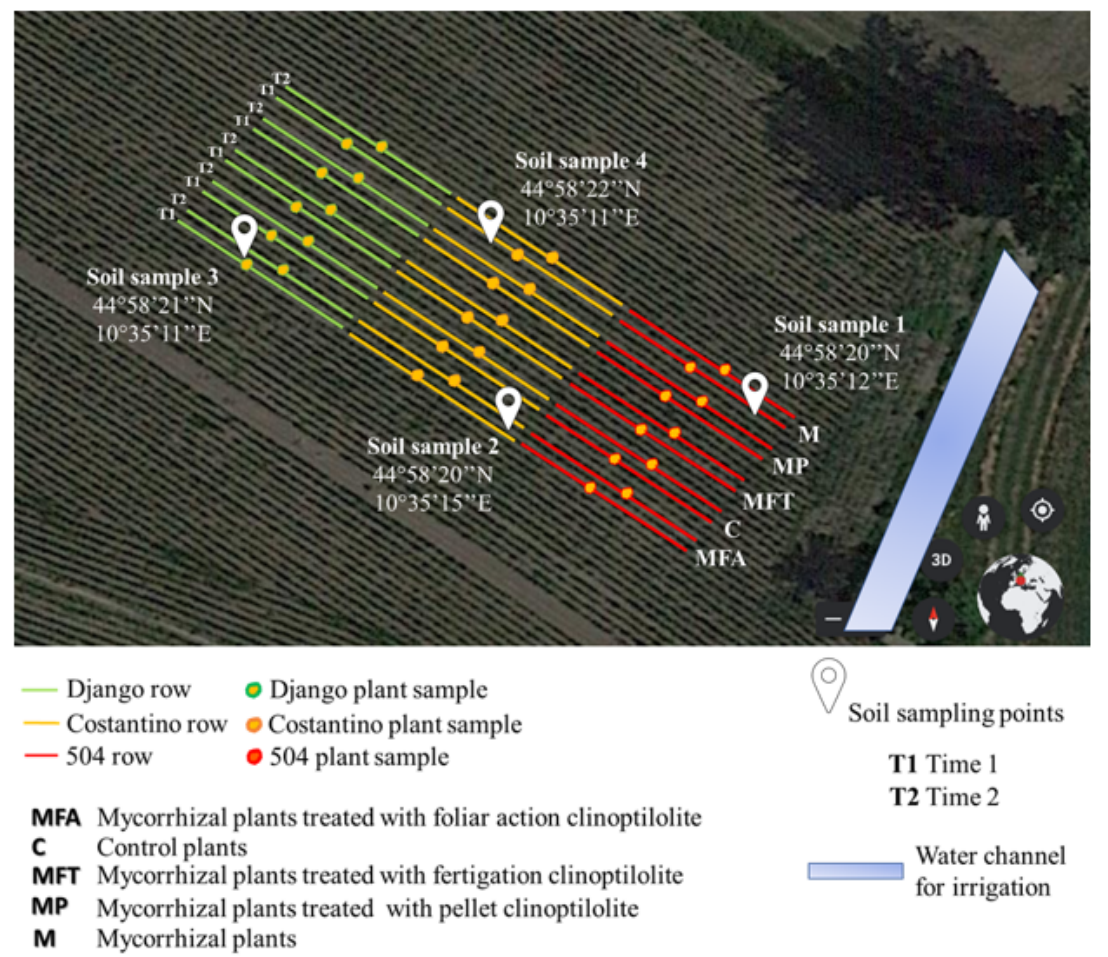

Figure 1

Experimental field. Soil and plant sampling positions are indicated. Plants were sampled from the inner part of each cultivar row to avoid as much as possible side effects from the different vicinal cultivars. 



\section{Figure 2}

Marginal means of $\mathrm{Cr}, \mathrm{Cu}, \mathrm{Pb}, \mathrm{Si}$, and $\mathrm{Ca}$ content of melon plants, expressed as dry weight ( $\mathrm{dw}$ ) for the tested treatments (C: control not treated; $\mathrm{M}$ : mycorrhization with Trichoderma; MFA: mycorrhization and application of clinoptilolite for foliar action; MFT: mycorrhization and application of clinoptilolite in fertigation; MP: mycorrhization and application of clinoptilolite pellet). Error bars represent the standard errors and different lower-case letters indicate significant differences ( $\mathrm{p}$-value $<0.05)$ between treatment:time interaction as determined by the Fisher's LSD test. 

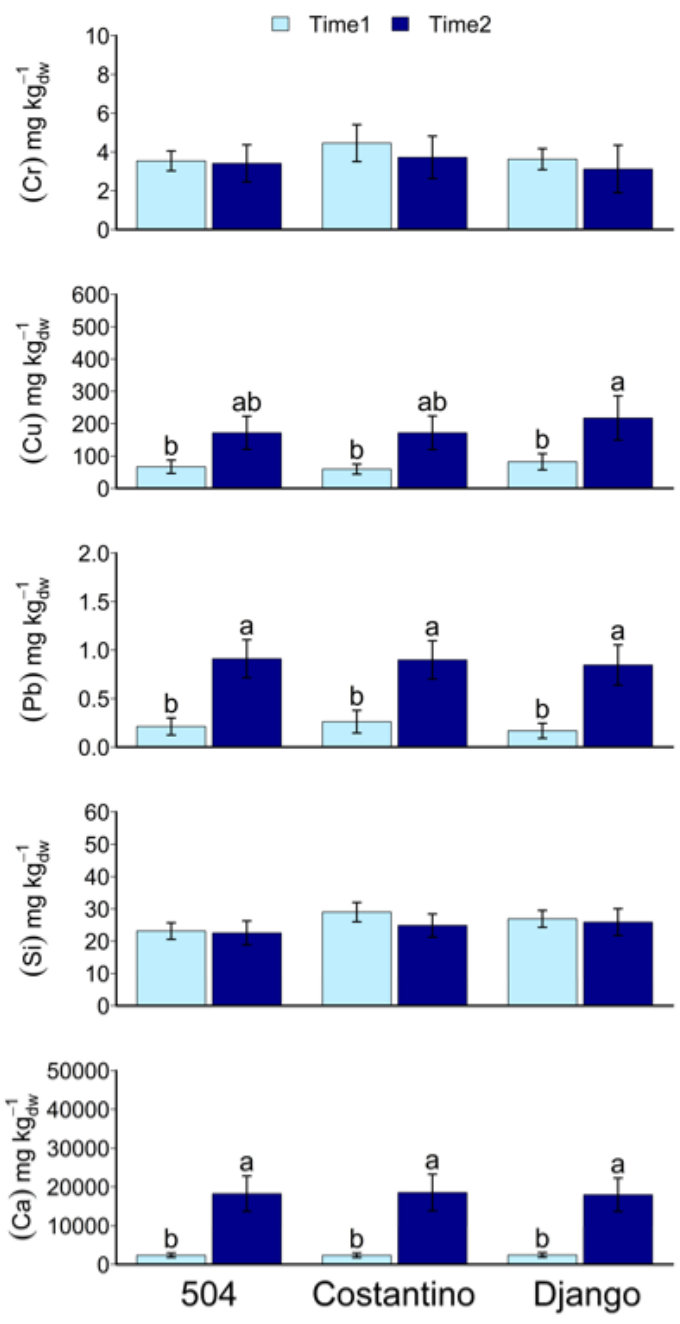

Figure 3

Marginal means of $\mathrm{Cr}, \mathrm{Cu}, \mathrm{Pb}, \mathrm{Si}$, and $\mathrm{Ca}$ content of melon plants, expressed as dry weight, for variety (namely, 504, Costantino, and Django). Error bars represent standard errors. Different lower-case letters indicate significant differences ( $p$-value $<0.05)$ between crop variety:time interaction as determined by the Fisher's LSD test. 
$\square$ Time1 $\square$ Time2
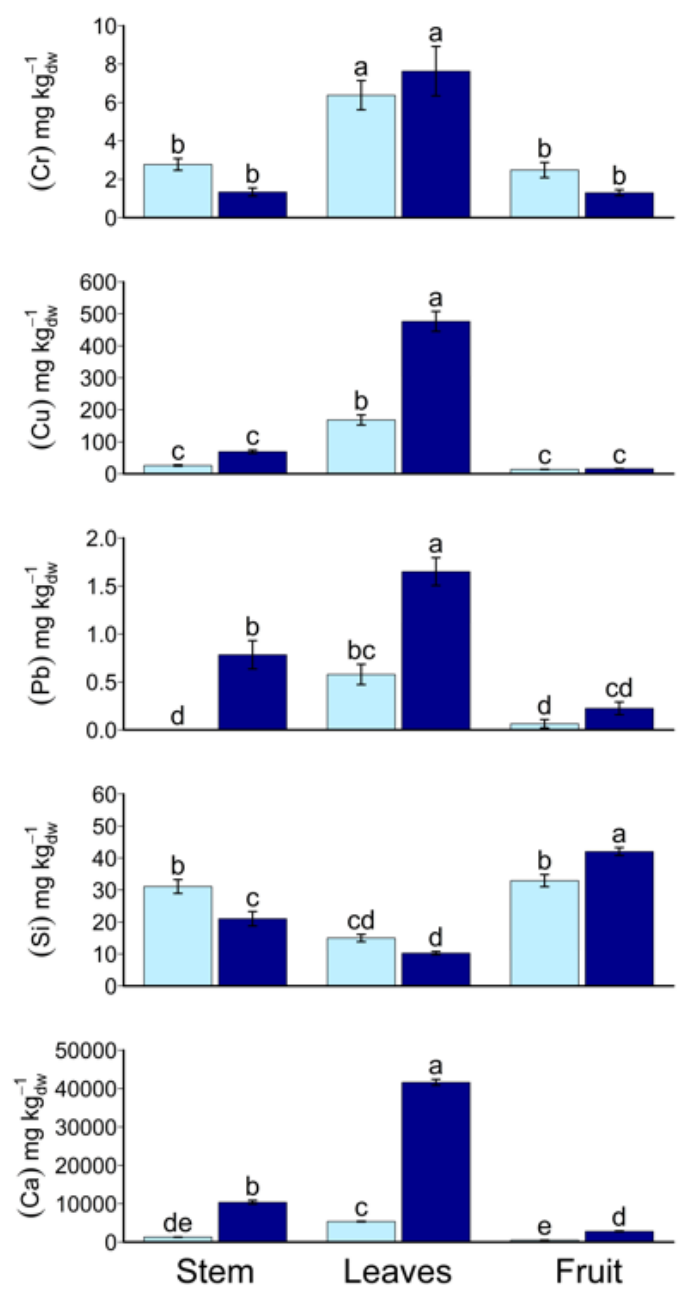

Figure 4

Marginal means of $\mathrm{Cr}, \mathrm{Cu}, \mathrm{Pb}, \mathrm{Si}$, and Ca content of plant fractions (stem, leaves, and fruit) expressed as dry weight. Error bars represent standard errors. Different lower-case letters indicate significant differences ( $p$-value $<0.05)$ between plant fractions:time interaction as determined by the Fisher's LSD test.

\section{Supplementary Files}

This is a list of supplementary files associated with this preprint. Click to download.

- Table2.docx

- Supportinglnformation.docx 